Religion and Gender, vol. 2, no. 2 (2012), pp.

328-347

www.religionandgender.org

URN:NBN:NL:UI:10-1-101606

ISSN: $1878-5417$

Publisher: Igitur Publishing (Utrecht)

Copyright: this work is licensed under a Creative

Commons Attribution License (3.0)

\title{
The Bible Student's Sacrifice: Gender Fluidity and Consecrated Identity in Evangelical America, 1879-1916
}

\author{
TIMOTHY ROBERT NODDINGS
}

\begin{abstract}
American feminist scholars have often represented gender in nineteenth-century evangelical Protestantism as a binary conflict between oppositional 'male' and 'female' categories of identity and experience. Drawing on the theoretical work of Jeanne Boydston, this article argues that gender within evangelical religion is better understood as a 'system of distinctions' that could be articulated in a variety of ways, some of which violated the gendered division of masculine/feminine. The American Bible Student movement, as a fervent millennialist organization, demanded that its members sacrifice their individuality to become 'harvest workers' for Christ. This sacrifice temporarily provided Students with a degree of freedom to construct spiritual identities that combined 'masculine' and 'feminine' signifiers, destabilizing the binary meaning of gender. After 1897, a series of internal challenges and schisms re-solidified the gender line, associating stability with the limiting of women's power within both church and home.
\end{abstract}

\section{Keywords}

Gender theory, evangelicalism, consecration, United States $\square$ 


\section{Author affiliation}

Tim Noddings is a graduate student at the University of Victoria, Canada, pursuing a master's degree in religious history. His interests include the history of evangelism, millennialism, and gender issues in American fundamentalism. Email: barak65@hotmail.com

\section{Introduction}

'Now, who has a burning desire to go and labor in the Vineyard, and has been praying that the Lord would open the way? This offer is made to you by the WATCH TOWER TRACT SOCIETY.' ${ }^{1}$

From 1879 until 1916, the American Bible Student movement led by Charles Russell urgently preached the imminent end of human government and arrival of Christ's Kingdom. Numerically, the Bible Students were miniscule - with only roughly 14,000 members in 1901 - but what they lacked in numbers they compensated for in sheer dedication to their millennial message of the imminent return of Christ. By the early 1880s, networks of travelling colporteurs and part-time salespeople sold or distributed Watch Tower magazines, tracts and books in the hundreds of thousands; 500,000 tracts in 1881 alone when the movement had a following of only a few hundred. ${ }^{2}$ Willing to travel and sacrifice personal wealth and security for their message of imminent transformation, Students took the Tower to Canada, Britain, Sweden, and Germany, and by 1900 had small congregations throughout much of the western world. ${ }^{3}$ The fervency of Student doctrine and its combination of religious practice with aggressive proselytizing would eventually transform the small group into the modern-day Jehovah's Witnesses, whose worldwide organization formalized and institutionalized the movement's door-to-door missionary work while also shifting many of its early doctrines. ${ }^{4}$ In the more loosely-

1 'Wanted 1000 Preachers' in ZWT, April 1881. Unless otherwise marked, all Watch Tower articles cited were authored by Charles Russell.

2 Tony Willis, A People for His Name, Morrisville, NC: Lulu Enterprises 2006, 25; the Students were able to distribute literature far in excess of the number of devoted Tower readers. In 1901, when there were 14,000 regular subscribers to the Watch Tower, the organization distributed 128,000 books and 2,591,500 tracts through canvassing. Ibid., 39.

3 Ibid., 24-31.

4 Literature on the Bible Students is largely contained within a few histories of the Jehovah's Witnesses movement. Most of these are now decades old and written by former members highly critical of the modern movement. For the most comprehensive coverage of the Russell era, see James M. Penton, Apocalypse Delayed: The Story of Jehovah's Witnesses, Toronto: University of Toronto Press 1985; Willis, A People for His 
organized nineteenth century, the Watch Tower work created a community that challenged its members to sacrifice their lives to Christ. In the process, new identities were generated that could test, obscure, or distort the categories which otherwise limited and defined their existence. American feminist scholars have long seen religious faith as a language that can both subjugate and empower, providing 'cosmological justification' for limiting women's sphere while also giving them the tools to challenge male authority. ${ }^{5}$ This scholarship has been invaluable in providing a historicized understanding of religious women as 'meaning-seeking actors' who hold some agency in their interaction with religious institutions. But it has also had the unfortunate consequence of setting up a binary relationship between struggle and oppression, particularly when focused on the world of nineteenth-century evangelicalism. Much of the historical literature has turned on conflict and difference, with a great emphasis on various forms of resistance: how women used certain doctrines, practices, and symbols to subvert or challenge larger religious discourses of female subordination. ${ }^{6}$ A number of authors have argued that a proto-feminist impulse or 'subtle feminist condemnation' of male leadership governed Protestant women's experiences in the period from the Second Great Awakening to the end of the Victorian era. ${ }^{7}$ Others have highlighted a common female religious culture that exists across time and denomination, organized around the concerns of maintaining the family and a desire for

Name; Alan Rogerson, Millions Now Living Will Never Die: A Study of Jehovah's Witnesses, London: Constable \& Co 1969; James Beckford, The Trumpet of Prophecy, A sociological study of the Jehovah's Witnesses, Oxford: Basil Blackwell 1975; also see the Jehovah's Witnesses official history, Jehovah's Witnesses-Proclaimers of Christ's Kingdom, New York: Watchtower Bible and Tract Society 1993.

5 Ann Braude, 'Forum: Female Experience in American Religion' in Religion and American Culture 5:1 (1995), 9.

6 Catherine Brekus, Strangers \& Pilgrims: Female Preaching in America, 1740-1840, Chapel Hill/London: University of California Press 1998; Virginia Brereton, From Sin to Salvation: Stories of Women's Conversions, 1800 to the Present, Bloomington: Indiana University Press 1991; Jeanette Rodriguez, Our Lady of Guadalupe: Faith and Empowerment among Mexican American Women, Austin: University of Texas Press 1994.

7 Karin Gedge, Without Benefit of Clergy: Women and the Pastoral Relationship in Nineteenth-Century American Culture, New York: Oxford University Press 2003, 173. For older work on American religiosity and proto-feminism, see Barbara Epstein, The Politics of Domesticity: Women, Evangelism, and Temperance in Nineteenth-Century America, Middletown, Conn.: Wesleyan University Press 1981, 9; Nancy Hardesty, Women Called to Witness: Evangelical Feminism in the 19th Century, Nashville: Abingdon Press 1984. 
more equality in church organization and the right to preach. ${ }^{8}$ Both of these claims rest on a distinction between a 'men's' and 'women's' culture within religion, which, in the words of Barbara Epstein, were 'each built upon the repudiation of the other's values. ${ }^{9}$ As a result, many scholars have understood historical women within religious institutions as existing in a regular state of tension and competition with men.

A great deal of valuable and informative work has emerged based on the above approach to gender and religious history. But this article will suggest that there are at least two negative consequences of an emphasis on difference and conflict in the field. The first relates primarily to theoretical developments in the field of gender. The emphasis on the oppression/resistance of women within religious institutions reflects a disciplinary assumption that oppositional gender categories are foundational to how gendered power is organized and experienced. As in other areas of the field, women's and gender historians studying religion have made widespread use of Joan Scott's groundbreaking understanding of gendered symbols as 'signifiers of power'. ${ }^{10}$ Yet, while the continued utility of Scott is obvious, the late Jeanne Boydston has recently pointed out the danger of accepting a binary organization of gender as the only means by which it can be signified. ${ }^{11}$ Historians working from preconceived categories of analysis tend to impose a 'process of reduction' on their sources, smoothing over their roughness and complexity in order to fit them within the rubrics of gender, race, and class. As a result, categories of analysis ultimately must 'reflect and replicate our own understandings of the world', making it difficult to hear the discordant tones and relationships which could undermine them. ${ }^{12}$ Boydston recommends instead that gender as a category be understood not only as a signifier of power, but as a fluid 'system of distinctions' that can be manifested in a

8 Ann Braude, Sisters and Saints: Women and American Religion, Oxford: Oxford University Press 2008.

9 Politics of Domesticity, 64.

10 Joan Scott, 'Gender: a Useful Category of Analysis' in American Historical Review 91: 5 (1986), 1069.

11 'Scott's model of gender ... virtually ruled out (as naive) distinctions between male and female that might not be about this kind of differentialising power. Within this category, it is difficult to imagine distinctions between males and females that are not invidious to one or the other group, and thus correspondingly difficult to conceive of distinctions that do not register as primary axes of allocating authority.' Jeanne Boydston, 'Gender as a Question of Historical Analysis' in Gender and History 20:3 (2008), 563-64.

12 Ibid., 560. 
variety of ways outside of a oppositional gender binary. ${ }^{13}$ The advantage of such an approach is its ability to imagine masculinity and femininity not simply as fixed categories set in eternal opposition, but as systems of meaning that, while often rigid, could also be represented in ways that blur and undermine the gender line.

A second consequence of the emphasis on conflict relates primarily to developments within North American religious history. While earlier scholars tended to privilege theology, the growth of 'lived religion' scholarship since the 1990s focused a social and cultural lens on religion in order to understand how it was experienced and practised by believers. This required a search for new sources, in some cases leading to a nearly ethnographic approach relying heavily on interviews and field studies, and in others to a new attention to letters and testimonials as crucial sources of social history. ${ }^{14}$ It also emphasized the 'staggering varieties' of religious experience, which can reveal unusual 'complexities and ambiguities' in the relationship between gender and religion. ${ }^{15}$ The lived religion approach challenges gender historians to both place a greater emphasis on how religion is practised and experienced, and to search for the 'ambiguities' concealed within understandings of gender as a binary conflict between masculine and feminine.

In the 1880s, the Pennsylvania-based Zion's Watch Tower magazine preached an evangelical gospel that called all readers to 'work the harvest' of Jesus Christ. Unlike the exhorters of the Second Great Awakening, the Watch Tower did not require that its followers organize revivals or become itinerant preachers. Instead, it defined 'working the harvest' as buying bundles of the organization's literature and selling them door-to-door, on

13 Boydston has suggested the phrase 'systems of distinction' as a replacement for 'signifiers of power,' reflecting a broader understanding of gender as situational and relational. See ibid., 565.

${ }^{14}$ For a near ethnographic approach, see Marie R. Griffith, God's Daughters: Evangelical Women and the Power of Submission, Berkeley: University of California Press, 1997; for a more typical approach that combines interviews with the use of published and unpublished letters and testimonials, see the introduction of Robert Orsi, Thank You, St. Jude: Women's Devotion to the Patron Saint of Hopeless Causes, New Haven, Conn.: Yale University Press 1996.

15 Robert Orsi, Between Heaven and Earth: The Religious Worlds People Make and the Scholars Who Study Them, Princeton: Princeton University Press 2005, 191. For other important work in the field of lived religion related to the study of gender, see Ann Taves, Fits, Trances, and Visions: Experiencing Religion and Explaining Experience From Wesley to James, Princeton: Princeton University Press 1999 and essays in Women and Religion in the African Diaspora, Marie Griffith and Diana Savage (eds.), Baltimore: John Hopkins University Press 2006. 
street corners, or outside the doors of hostile churches. But even if the Watch Tower Bible Students didn't act like eighteenth-century Shakers or Methodists, their work still united men and women in a common spiritual quest to prepare the Lord's coming and sacrifice the flesh for the spirit. The harvest was a metaphor that transformed the mundane task of selling the Tower into a spiritual romance that brought followers together in a common work to spread the news of the New Kingdom. And - at least for a time - this was a work that called into question what gender meant in a religious context.

This article draws on Boydston and the lived religion school to explore how gender worked as a system of distinctions within the American Bible Student movement from its founding by Charles Russell in 1879 to his death in 1916. It argues that the doctrine and metaphors of the early Student movement set up separate standards of Christian femininity and masculinity, but ultimately subordinated both to the need for a 'total consecration' to the harvest work. The role of the harvest worker allowed men and women to experiment with their identities as participants and 'saints' in the Bible Student movement. Students imagined themselves in a variety of ways, sometimes conforming to gendered distinctions, and sometimes existing at least partially outside of them. Of course, the world of Student religious practice and how they 'lived' their religion is now closed to us. However, it is possible to partially reconstruct how Students saw their religious identities through the letters and testimonials they published in the Watch Tower. While Charles and Maria Russell never endorsed sexual equality, the language of sacrifice and devotion they preached eroded the difference between how men and women presented themselves as spiritual workers in the Tower letters, creating the possibility for Students to imagine identities which transcended gendered distinctions. These challenges to the gender binary were never dominant, but their very existence should raise questions about how historians categorize gender within religious spaces. This process is similar to the attempt of some historians of sexuality to 'queer' sex, defined by Annamarie Jagose as the process of 'dramatizing incoherencies' in 'allegedly stable relationships.' ${ }^{16}$ By dramatizing the incoherencies, discontinuities, and undercurrents surrounding religious practice and gender among groups like the nineteenth-century Bible Students, other stable relationships may be revealed as concealing a far more uneven and multifarious reality.

${ }^{16}$ Annamarie Jagose, Queer Theory: An Introduction, New York: University Press 1996, 2. 
The first section of this article will focus on how Charles and Maria Russell's Watch Tower articles attempted to re-order the gender roles of men and women to make both compatible with the self-sacrificing, public labour of the harvest worker. The Russells walked a fine line between redefining masculinity and femininity in a spiritual context and overturning the gendered hierarchy of both scripture and state. Neither Russell intended to totally reject the separate 'natural' spheres of men and women, but the metaphors produced by this balancing act worked against the systems of distinction that both tried to carefully maintain. Section two, drawing on lived religion approaches, will examine the 'practice' of Bible Students in how they presented their religious identities in the Watch Tower letters. While written letters and testimonials do not necessarily reflect the social experience of Students, they were one way in which Students expressed their membership as part of the larger spiritual community and served as an example to others of how to act and behave. As a result, along with the writings of Charles and Maria Russell, they partially defined what it meant to act and live as a Student. The metaphors these authors chose in constructing their harvest identities reveals crucial evidence that the movement could in practice not only re-order the gender binary, but for a time de-stabilize it. The last section will examine the anxieties born of this blurring of male and female spheres in the 1890s and 1900 s, which led to a determined effort to solidify the gender binary by placing the sexual hierarchy above faith within the harvest work.

\section{Defining from Above: Gender in Early Bible Student Doctrine}

The Bible Students began as an intensely millennial organization, founded on the belief that the apocalypse was due to begin in 1914 CE. ${ }^{17}$ Charles Russell, an Allegheny businessman and department store owner with no religious training, reached the date through his relationship with the Adventist Nelson H. Barbour, who was convinced that Bible prophecy predicted that Christ was to return 2,520 years from the fall of Babylon in 607 BCE. ${ }^{18}$ Although Russell soon broke with Barbour, he retained the 1914 date, teaching through his magazine Zion's Watch Tower that the years left until then were 'the time of the harvest'. This was a prophetic period set aside by Christ to gather the 'small flock' of true Christians out of the false

17 Penton, Apocalypse Delayed, 14.

18 In fact, John A. Brown actually came up with this millennial prediction first in 1823, though he arrived at the year 1917. Brown's eschatology was later adapted by Barbour and shifted three years earlier. See Penton, Apocalypse Delayed, 21-22. 
churches of Christendom in preparation for the imminent destruction of the world. The work of gathering fell to those whose destiny it was to hear the Tower's call and become anointed as saints - the bridal class of Christ who would rule as 'kings and priests' alongside his throne in heaven. ${ }^{19}$ The later failure of the 1914 date, along with Russell's death two years later, would throw the Bible Students into crisis and schism, leading the largest body of remaining Students under J.F. Rutherford to re-order the Watch Tower's original millennial doctrine and form the Jehovah's Witnesses in $1931 .^{20}$ But in the 35 years from 1879 to 1914, the imminent return of Christ seemed assured to Russell and his followers.

The gathering or 'harvest' work was primarily defined as spreading the word of Russell and the Watch Tower to all those who would listen, a consecrated task which established the believers' place as part of the prophetic cycle that would culminate after 1914. Consecration was an act of faith which required Students to withdraw from the earthly world, slated for destruction, and dedicate their energy, ability and independence to the higher labour of canvassing for the organization. Those who were successful in doing so were promised not only eternal life, but were also transformed into a spiritual class set apart from others. By demonstrating their faith in the imminent end of human government, Students gained membership as one of those anointed to serve in Christ's heavenly kingdom. Harvest work was therefore not just a task Students performed, but the proof of their consecration that signalled membership in the larger Watch Tower community.

This kind of radical devotion was nothing new in evangelical history. Many of the revivalist movements of the Second Great Awakening also believed that their followers were New Creatures in Christ who needed to sacrifice their earthly life for the prize of consecration. ${ }^{21}$ The world of America in the 1880s was, however, far removed from the burned-over districts and religious fervor of the early decades of the century. The economic transformation of the United States in the first half of the nineteenth century accompanied a shift to values that were less

${ }^{19}$ Charles Russell, Studies in the Scriptures, Vol. 1, New York: Watchtower Bible \& Tract Society $1886,81$.

20 The modern day Jehovah's Witnesses continue to recognize the 1914 date, but teach instead that it marked the beginning of Christ's invisible return, not the culmination of Armageddon. See Jehovah's Witnesses-Proclaimers of Christ's Kingdom, 162-170.

${ }^{21}$ Lawrence Foster, Women, Family, and Utopia: Communal Experiments of the Shakers, the Oneida Community, and the Mormons, Syracuse, N.Y.: Syracuse University Press 1991; G.A. Rawlyk, The Canada Fire: Radical Evangelicalism in British North America, 1775-1812, Kingston and Montreal: McGill/Queen's University Press 1994. 
accommodating to older models of religious enthusiasm. Victorian notions of separate spheres and the establishment of America as a middle-class nation placed new importance on gender as a mark of identity and a signifier of power for a large segment of American society. Men, as breadwinners and businesspeople, were expected to be active in the public and profane world of work and commerce, leaving the spiritual to the domestic sphere of their wives. At the same time, new notions of domesticity and womanhood demanded that women remain within the private realm of home and conform to a passionless ideal that rejected the emotional and public nature of the religious revival. ${ }^{22}$ While these roles were not entirely new and remained segmented by class, by the second half of the nineteenth century gender was central to how even devoutly evangelical Americans negotiated their religious and secular identities in an industrializing America. ${ }^{23}$

In part, the Bible Students reflected the evangelical ideal of the past, rejecting definitions of gender that placed material comfort and respectability above the need for consecration. Charles Russell personally attacked the male ideal that 'sustenance' was 'the principle aim and interest of life' and 'the standard by which all other interests were estimated. ${ }^{24}$ Whether common labourer or wealthy businessman, men had become 'selfish, greedy, and grasping' and were being 'swallowed up ... by money-getting' in Satan's world. ${ }^{25}$ By contrast, the consecrated saint placed spiritual matters first and embraced a more ascetic ideal: ' $[\mathrm{H}] \mathrm{e}$ is weaned from earthly ambitions, and labors not for earthly things ... having (needful) food and raiment ... therewith be content. ${ }^{26}$ Instead of pursuing material gain, Russell urged men to contract with 'the Lord's business' and

22 For a classic account of the female 'Cult of Domesticity,' see Nancy F. Cott, The Bonds of Womanhood: 'Women's Sphere' in New England, 1780-1835, New Haven: Yale University Press 1977; for Victorian masculinity, see the essays in Mark Carnes and Clyde Griffen (ed.), Meanings for Manhood: Constructions of Masculinity in Victorian America, Chicago/London: University of Chicago Press 1990.

${ }^{23}$ It is important to remember that notions of domesticity and breadwinning were highly segmented by class. Working-class religious movements like the Salvation Army were less restricted by notions of female domesticity, and granted significant opportunities for women to enter the public sphere. See Lynne Marks, Revivals and Roller Rinks: Religion, Leisure, and Identity in Late-Nineteenth-Century Small Town Ontario, Toronto: University of Toronto Press 1996, 169-188. For the United States, see Lillian Taiz, Hallelujah Lads and Lasses: Remaking the Salvation Army in America, 1880-1930, Raleigh: University of North Carolina Press 2001.

24 Russell, Studies in the Scriptures, Vol. 1, 310.

${ }^{25}$ Ibid.; 'The Footsteps of Jesus' in ZWT, June 1881.

26 Ibid., 339-340. 
act as 'God's stewards' for the earth, embracing service as a higher calling that removed them from Satan's world and prepared them for their heavenly future. ${ }^{27}$

Maria Russell, Charles Russell's wife and a crucially important figure in the early period of the magazine, was responsible for the parallel rearticulation of femininity within the harvest work. This was a more difficult task than reconciling masculinity to consecration. Unlike men, women faced both cultural and scriptural barriers to their participation in public preaching. Pauline doctrines of male headship in the family and female subordination within the church clashed with expectations that women spread the news of the Watch Tower outside of the home. Maria Russell affirmed in her articles that gender equality was unscriptural, and that man was 'superior to woman, the weaker vessel.. ${ }^{28}$ But while acknowledging that the sexes were not equal, she pointedly stated that domesticity and male headship could not keep women from the harvest ministry:

We have nothing to say to those Christian women who find both the center and circumference of their desires and efforts to do good within the comparatively narrow sphere of home, except that they are living far below their privilege, and that selfishness, and not the glory of God chiefly, is the mainspring of their efforts. ${ }^{29}$

Like men, women could not serve both God and the world if they were to make a 'SACRIFICE of the flesh of human nature' and achieve consecration in the harvest. ${ }^{30}$ Domesticity, like the pursuit of wealth, was an obligation that distracted women from the spiritual. For this reason, Maria Russell instructed women to avoid marriage and children - those 'entanglements of an earthly character' - that deflected them from their consecrated work. ${ }^{31}$ Maria and Charles Russell themselves never consummated their marriage as part of their own consecrated sacrifice to the work. ${ }^{32}$

Married women who already had families were a more difficult case. Maria Russell acknowledged wives and mothers as having a responsibility to the home from which they could not be released. As an

27 'The Commission of the Apostles' in ZWT, 1 May 1893; 'Lay up for yourself Treasures' in ZWT, February 1881; 'Forsaking All' in ZWT, June 1886.

${ }^{28}$ Maria Russell, 'As Becometh Women Professing Godliness No. 1' in ZWT, October 1888.

29 Ibid.

30 Maria Russell, 'The Little Flock and the Great Company' in ZWT, July 1885.

31 Maria Russell, 'As Becometh Women Professing Godliness No. 2' in ZWT, December 1888; Charles Russell also advised men against marriage. See for example ZWT, 1 March 1895.

32 'Truth is Stranger than Fiction' in ZWT, 15 July 151906. 
alternative, she suggested that they find ways to reconcile spiritual and familial obligations by rising earlier, doing away with non-essential housework, and maintaining simplicity of dress. ${ }^{33}$ But if faced with opposition to their spiritual work, Maria Russell made it clear where women's higher loyalty should lie: 'Our first allegiance is to our heavenly Bridegroom; and where his counsel is called in question, there is but one proper course, and that is, loyalty to him at any cost. ${ }^{34}$ Echoing at least faintly the potential for the radical de-gendering through evangelism that marked the First and Second Great Awakening, Maria Russell was emphatic that consecration supplanted even a woman's domestic obligations:

The worldly husband is not the head of the wife as a 'new creature' espoused to Christ. Her first allegiance is therefore to her real though invisible Lord, but in so far as may be consistent with her new relationship she should endeavour to fulfill the old also-a thing not possible in every respect. ${ }^{35}$

This did not mean that women were free to abandon their families or assume positions of authority over men. Women were to conform as closely as possible to the domestic ideal, and in their public work to act with a 'modest, quiet, demeanour, in action, word, and apparel' to protect the feminine character often lost by 'those who attempt to work in a public way. ${ }^{36}$ But when these two standards clashed, consecration ranked higher than domesticity.

Charles and Maria Russell both rearticulated gender in the Watch Tower in ways that rejected key aspects of conventional masculinity and femininity by placing the obligations of consecration above the responsibilities of breadwinning and domesticity. Yet, even for New Creatures in Christ, there were limits to how far the harvest work could challenge the gender binary. By expecting women to maintain their 'modest, quiet' demeanour and formally adhering to the scriptural hierarchy of the sexes, the Russells represented the harvest in gendered terms. But while never endorsing equality between the sexes, the Tower unquestionably placed the movement above earthly concerns. This was the

\footnotetext{
33 Maria Russell, 'As Becometh Women Professing Godliness No. 4' in ZWT, March 1889.

${ }^{34}$ Ibid.

35 Ibid.; for the de-gendering potential of religion in the eighteenth century, see Susan Juster, Disorderly Women; Susan Juster, 'The Spirit and the Flesh: Gender, Language, and Sexuality in American Protestantism,' in Harry Stout and Darryl G. Hart (eds.) , New Directions in American Religious History, New York: Oxford University Press 1997, 334361; Brekus, Strangers and Pilgrims.

36 Russell, 'As Becometh Women Professing Godliness No. 1.'
} 
message that rang out most clearly to the early Bible Students, shaping how they constructed their own identity as reapers in Christ's harvest.

\section{Defining from Below: Gender in the Watch Tower Letters}

In the 1880s, the Tower and its sister publications called Christians to consecrate themselves fully to the harvest and at the same time respect the gender binary. However, once harvest metaphors left the pages of the Tower they quickly escaped the Russells' control. The letters and testimonials regularly published therein reveal that Students imagined their role as consecrated saints in a wide variety of ways, some of which undermined the gender line to which the Russells continued to adhere.

Many gender historians like Virginia Brereton have argued that gendered language shaped how nineteenth-century evangelical conversion experiences could be felt and expressed, with men and women drawing on different metaphors while forming their spiritual identities. ${ }^{37}$ A number of Watch Tower letters fit within this pattern, with men and women imagining their spiritual identities in different ways that reflected the gendered hierarchy of the organization. However, returning to Jeanne Boydston, it is important to note that a significant number of other letters fail to break down neatly into one category or the other. Many writers drew on both 'feminine' and 'masculine' scripts, casting some doubt onto the meaning of these labels within the organization. This section will argue that by imagining gender within the Bible Students outside of a strictly oppositional binary, important undercurrents become visible. Conventionally masculine and feminine metaphors could be employed in ways which blurred their gendered meaning, revealing a more complex process at work. This is not to say that oppositional frameworks of gender ever ceased to exist among the Bible Students. But alternative representations were not only possible, but for a time numerous, challenging our own understanding of how to divide and categorize those Students whose testimonies were preserved in the pages of the Tower.

Metaphors of independence and fortitude were popular staples of men's letters. In such texts, consecration was less of a sacrifice and more of a tonic that gave Christians the strength to resist and struggle against the ignorance of the world. The 'clear and forcible' teachings of the Tower

37 Brereton, From Sin to Salvation; also see Epstein, Politics of Domesticity, 45-65; Brekus, Strangers and Pilgrims, 179-181; Hardesty, Women called to witness, 115-140. For masculine figurings of evangelicalism, see Bendroth, Fundamentalism and Gender, 2024. 
offered freedom from the 'shackles' of superstitious creeds: '[W]hereas I was once a bond-slave, now I rejoice in the liberty of the gospel of our Lord and Savior, Jesus Christ. Oh what a glorious liberty it is! $!^{38}$ Other male writers eschewed the language of surrender by figuring themselves as warriors for Christ 'not ashamed to own their Lord nor to defend his cause' and to 'speak the truth with boldness.' 39 To 'own the lord' was to 'run yourself to death' in the harvest and set your 'face like flint to the world', a sentiment that went so far as to lead one man to rejoice that God allowed Satan to test his faith, thereby proving he was in a state of consecration. ${ }^{40}$ Images like this transformed sacrifice into an active act in which the Students' personal reserve of faith empowered them to overcome opposition and achieve greatness in the harvest work.

However, all of these metaphors were drawn on by women as well to construct similar identities in the harvest. One married woman claimed her family had threatened to put her in an asylum if she did not cease reading and handing out the Tower. After wavering for a time, she returned to the Students and withdrew from the Baptist church: '[T]hank God, I ... am now free. I am free with the liberty wherewith Christ has made me free, and with his help, I will never again be entangled with the yoke of bondage. ${ }^{41}$ Another described standing alone outside of a Baptist church following services to pass out anti-evolution pamphlets. This act required 'patience and fortitude', and 'had seemed to me an impossible thing for me to do ... [but] I felt I must overcome at any cost, or grieve the spirit. ${ }^{42}$ As with men, this language sometimes embraced the possibility of persecution and hardship as a divine chastisement which purified a sainted harvest worker and proved their consecration. One woman wrote of how she would not 'flinch when the cleansing [in the harvest] comes', and instead rejoiced to be allowed to suffer for the work of preaching Christ's coming glory. ${ }^{43}$ Women as well as men could figure struggles in the harvest as a test of personal resilience and fortitude which demonstrated their membership among the consecrated.

Other metaphors in Bible Student letters figured the writer with martial identities as warriors or crusaders for Christ. As with metaphors of fortitude and resilience, these identities were available to both genders,

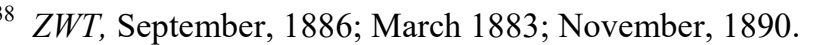

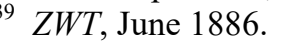

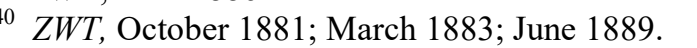

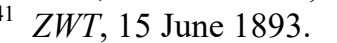

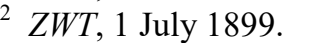

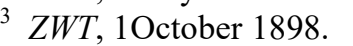


even if men favoured them more often. Male Students imagined that they wielded 'the sword of truth against mighty foes' at 'the forefront of the battle, contending earnestly for the faith. ${ }^{44}$ One male writer even referred to Watch Tower literature as the 'small shot, grape and canister' he fired against the forces of Christendom. Yet women also made use of martial language, particularly in the form of poetry. In 'I Am the Way', Mrs. Abiel Bowen took on the voice of Christ and called all Students to 'Gird on thee thine armor bright! I, thy Captain, lead the fight; Up, and battle with thy might! God will guard and keep thee right. ${ }^{45}$ Talk of 'spiritual armour' and 'swords of truth,' drawn directly from scripture, peppered the letters of other men and women, melding with metaphors of endurance and struggle in the creation of assertive spiritual identities.

Metaphors of fortitude or war were active scripts in the Bible Student letters, empowering the writers with an independent identity in the harvest work as they struggled to spread the message of the Tower. While such metaphors were always important, passive scripts of surrender were even more crucial for representing the consecration and harvest experience. Women drew on this language most readily, conforming to Maria Russell's notion of the 'modest, quiet' woman worker. One writer disappointed at being forced to spend time away from the harvest felt her failure was not a test but a divine chastisement: 'I suppose I must always be content to do a little. Perhaps were I permitted to be a really efficient worker, I should get to thinking of myself more highly than I ought to think. ${ }^{46}$ Women's use of sacrificial language was not always so disempowering; the language of surrender could also be used to shroud participation in the harvest in the terms of passive femininity: '[I]t is all of Christ and nothing of self ... I am now a mere drone in the bee-hive of earnest workers, but I leave that all to the master of the harvest ... resting with childlike confidence in my Lord.' 47

Historians have noted how this 'vessel of Christ' language could turn notions of domesticity on their head and empower women to enter

\footnotetext{
${ }^{44}$ ZWT, May 1891.

45 Mrs. Abiel Bowen, 'I Am The Way' in ZWT, February, 1891; American women outside of religion also could at times imagine active martial identities through poetry. See for example Rachel Hope Cleves, 'Heedless Youth': The Revolutionary War Poetry of Ruth Bryant, 1760-1783' in William \& Mary Quarterly 67:3 (2010), 519-548.

46 ZWT, December 1892.

47 ZWT, January 1893.
} 
the public sphere. ${ }^{48}$ But it is often overlooked that men made widespread use of these metaphors as well. One male harvest worker wrote 'I am discouraged ... you cannot know how alone I am, and set aside as evil. I could not bear it but for God. ${ }^{49}$ Another tormented by his decision to leave his old church to enter the harvest declared 'I am so near the wall that my being cries out with anguish-hard pressed by the flesh and Satan ... Verily God has been leading me; I have no purpose of my own. ${ }^{50} \mathrm{~A}$ third claimed that after reading the Tower he now rested 'wholly upon the blood of Jesus. ${ }^{51}$ Self-effacing language and a loss of identity in Christ where not solely the preserves of women, but were a central piece of the evangelical experience that men could and did draw upon in figuring their religious experiences.

Viewing men's and women's letters together, the line between masculine and feminine language becomes obscured. Metaphors of independence, bondage, sacrifice, freedom, surrender, and war were all parts of the doctrine of consecration, and available to all Students imagining their place in the harvest. Sometimes these images were weaved together. A letter from Brother Adamson took pride in the 'vigorous and patient warfare' he had waged in the harvest, yet he also claimed that in it he was 'not only stimulated, but subdued, under the mighty hand of God. ${ }^{52}$ There was no contradiction in imagining oneself as both a soldier and a vessel of Christ - both were integral in defining what it meant to be consecrated. Again returning to Jeanne Boydston's argument, prior to 1900 gender among the Bible Students operated as a system of distinctions which could blur and challenge the gender binary. Charles and Maria Russell may have continued to adhere to gendered distinctions as signifiers of power, but in practice consecration for Bible Students drew on scripts that could be represented as both masculine and feminine. Women were more likely to draw on the language of surrender and men on scripts of martial Christianity, but each was an aspect of the consecration that was open to both in how they imagined themselves in the Lord's harvest. Rather than operating within an oppositional model of gender, masculine and feminine distinctions were re-ordered within the early Bible Student

\footnotetext{
48 See Griffith, God's Daughters, 169-198; for similar language in a spiritualist context, see Anne Braude, Radical Spirits: Spiritualism and Women's Rights in Nineteenth-Century America, Bloomington: Indiana University Press 1989, 84-86.

49 ZWT, September. 1885.

50 ZWT, February. 1887.

51 ZWT, January. 1893.

52 ZWT, 15 September 1893.
} 
movement in ways that blurred the division between the two and created new possibilities for identities that did not strictly conform to the gender binary.

\section{'Metes and Bounds': Working to Solidify the Gender Binary}

In the mid-1890s, the metaphorical fluidity surrounding consecration in the harvest began to break down as the Watch Tower paid closer attention to the proper spheres of men and women. Two schisms that related to issues of gender rocked the organization in 1894 and 1897. The first, led by four senior brothers and their wives, attacked Charles Russell for putting his followers 'under bondage' and mistreating his wife Maria Russell. ${ }^{53}$ The schism failed when Maria rejected the allegations and undertook a series of 'parlour talks' in congregations from Chicago to New York to discredit the dissenters. ${ }^{54}$ However, Maria Russell soon found herself at the center of a second crisis. While she had come to her husband's defence in 1894, in private the couple's relationship was already deteriorating. Charles Russell had become concerned that his wife's 'self-appreciation' was increasing because of her public role in quashing the revolt, and over the next three years the two began to quarrel over control of the magazine..$^{55}$ By 1897 , events had reached a breaking point when Charles Russell summoned a meeting of fifty Bible Students in Allegheny to excommunicate two of Maria's sisters for 'slanderous and false statements' made against him. ${ }^{56}$ The resulting conflict, which Charles Russell would later call 'the woman's rebellion', was quickly extinguished, with Maria Russell shortly thereafter leaving the organization in protest and separating from her husband. She would go on to later, in 1902, publish a tract criticizing Charles' attitude towards women. In response, Charles Russell ceased providing her financial support, leading Maria to sue for divorce on the grounds of mental cruelty. In 1908, she was granted a divorce with alimony, finalizing the dissolution of the two-decade partnership that had served as an example to Student harvest workers since the 1880 s. $^{57}$

53 'A Conspiracy Exposed!'in ZWT, April 25, 1894.; Penton, Apocalypse Delayed, 35-36; see also ZWT, 15 June 151894.

54 'Truth is Stranger Than Fiction' in ZWT, 15 July 1906.

55 Ibid.

56 Ibid.

57 The two principle accounts of the 1897 split between Charles and Maria Russell is Charles Russell's lengthy article in the 15 July 1906 article of the Watch Tower explaining the divorce suit and Maria Russell's 1902 tract laying out her side of the conflict. See 'Truth is Stranger Than Fiction' in ZWT, 15 July 1906; Maria Russell, 
It is not surprising that Charles Russell and the Watch Tower organization became more sensitive to gendered hierarchies after 1900. As historians have long noted, the process of institutionalization within organized religion reduced women's opportunities to step outside of conventional gender roles. ${ }^{58}$ When fringe revivals gained legitimacy and moved towards the mainstream of established sects, concern over respectability gradually overwhelmed earlier emphases on the devotion and spiritual equality of all followers. The feud between the Russells occurred at a time when the Bible Students were shifting from a series of loosely connected congregations in the Midwest into a national network headquartered in Brooklyn. Along with the growth in numbers came increased supervision over the harvest. After 1889, a series of national conventions provided instructions on proper methods of canvassing the Watch Tower and began the process of rationalizing the work, gradually replacing the earlier ad-hoc method of preaching with assigned territories requiring regular progress reports from the field. ${ }^{59}$ A year later, Russell created the 'Pilgrim' service, which nominated travelling representatives from Brooklyn to visit and oversee the work of local congregations. ${ }^{60}$ In this new environment, Students were more constrained in forming harvesting identities than they had been in the open period of the 1880s.

Along with these organizational changes came a new emphasis on policing the boundaries of the sexes. Instead of men and women both sacrificing their independent identities for the harvest, Charles Russell now declared that husbands and wives had sharply differing spiritual roles that could not be transcended even as New Creatures. If women violated their earthly spheres for spiritual work they got 'into a position of great danger; because several of the peculiarities of her sex ... which go to make her a true woman and attractive to true men will conspire under the unnatural conditions to spoil her womanhood - to make her "mannish". ${ }^{61}$ Manhood in the family would be eroded in such circumstances by the presence of ambitious women: 'The man under such conditions would gradually lose

'Readers of 'Zion's Watch Tower' and 'Millennial Dawn': Attention!', self-published, 1902.

58 See Carroll Smith-Rosenberg, 'Women and Religious Revivals: Anti-Ritualism, Liminality, and the Emergence of the American Bourgeoisie' in The Evangelical Tradition in America, ed. Leonard I. Sweet, Mercer University Press, 1984, 199-231.

59 'Suggestive Hints to New Colporteurs,' New York: Watch Tower Bible and Tract Society, 1910; 'Conventions,' in Index, Watch Tower Bible and Tract Society, 1994.

60 Rogerson, Millions Now Living Will Never Die, 14-15.

${ }^{61}$ Charles Russell, Studies in the Scriptures, Vol. VI, New York: Watch Tower Bible \& Tract Society, 1904, 266-267. 
what little manhood he possessed ... and become merely her tool, her slave.' ${ }^{62}$ The new concern with the threat assertive womanhood and passive manhood posed to the family and organization made the blurring of separate spheres in the harvest a danger that outweighed even the possible rewards of mutual consecration. ${ }^{63}$ Russell was now emphatic that the gender line needed to be preserved: 'Nature has set the metes and bounds of the sexes ... adapting each to the other so thoroughly that any interference with, or disregard of, her laws is sure to work injury in the end, however beneficial the changes may temporarily appear to be. ${ }^{64}$

A number of long-standing Bible Students dissented from the imposition of a strongly defined gender binary in the movement. In June 1908 , Charles Russell - claiming that he had received a number of letters complaining that brothers and sisters were inappropriately hugging and kissing one another - asked that all consecrated Bible Students take a vow not to be alone in the presence of a member of the opposite sex to whom they were not related. ${ }^{65}$ Russell was objecting to the custom of the 'spiritual kiss', an old evangelical greeting wherein Christians kissed one another on the lips as a show of affection without regard to gender. While this greeting had never before attracted controversy, in the new climate of the first decade of the twentieth century, Russell now felt that it let 'down some of the barriers of reserve which society has found by experience are absolutely necessary for the world', and was therefore dangerous. ${ }^{66}$ But, to Russell's great surprise, a 'small, but vigorous minority' of long-standing Students refused to swear the oath. ${ }^{67}$ As saints, these Students believed they had already consecrated themselves fully to the harvest, and felt that Russell's new pledge delegitimized their original conversion and called into question their status as New Creatures. Their spiritual identities, rather than their gender, determined how they interacted with one another in the movement. Russell, annoyed by the opposition, dismissed such arguments as 'amusing, ridiculous and self-contradictory', and insisted the vow was only meant to protect weaker Students from the danger of too much familiarity between the sexes. The disagreement was serious enough that

\footnotetext{
62 Ibid., 500.

${ }^{63}$ Susan Juster also found that a fear of 'disorderly women' helped spark a shift in gender relations among American Baptists at the end of the nineteenth century. See Juster, Disorderly Women, 145-218.

${ }^{64}$ Ibid., 267.

65 'Pay thy Vows unto the Lord' in ZWT, June 1908.

66 Ibid.

67 'What the Word Vow Signifies' in ZWT, 15 October 1908.
} 
ultimately several hundred Students - including Russell's own sister and nephew-in-law - broke off from the movement in 1908 as part of a larger schism over the doctrine of the New Covenant. ${ }^{68}$

Yet, while some older Students left the movement in response to its new emphasis on gender binaries, the majority of recent converts attempted to conform to the new gendered organization of the harvest. The widow Gertrude Seibert began a long career as a regular contributor of poetry to the Watch Tower after 1900. But unlike earlier women poets like Mrs Bowen, her verses for the magazine stressed patience and humility to women eager to embrace consecration: 'Can ye smile as His dear voice says tenderly, 'No,' When 'the field is so white,' and your heart yearns to go? Can ye rest then in silence, contented and still/ Till your Lord, the Chief Reaper, revealeth His will ?' ${ }^{69}$ In line with such sentiments, women who wrote to the Tower were now more cautious in how they framed their contribution to the harvest work. One recently-converted lecturer at a women's college wrote enthusiastically of her plan to use her public platform as a teacher to make new converts. However, she felt the need to add that by this she did 'not wish to be disorderly or bring any reproach' on the movement by speaking in public, and asked Russell for permission to proceed. He granted it on the condition she only repeated the words of the Tower, demonstrating to readers that women could continue to participate in the work only if they respected the bounds of the sexes and conformed to the male hierarchy of the church. ${ }^{70}$

Of course, the language of surrender and humility had always been an integral part of Bible Student religiosity. But the complex blurring of metaphors that had occurred in the 1880 s became less possible in the environment of the early twentieth century. Women were now far more likely to profess their meekness and subordination before God than they were to imagine themselves as hardy soldiers of Christ. Men, whose roles had been the subject of far less scrutiny, continued to enjoy more freedom, but were also now less likely to imagine themselves as weak and submissive vessels of Christ. The complex undercurrents and discontinuities which had existed in the first two decades of the movement receded under a new policing of the boundaries of gender. The possibilities for ambiguities and alternative imaginings which had existed earlier were now eclipsed.

\footnotetext{
68 Penton, Apocalypse Delayed, 40-42.

69 Gertrude Seibert, 'Are Ye Able?' in ZWT, 15 May 1912; see also Gertrude Seibert, 'Not Now My Child' in ZWT, 15 September 1907.

70 ZWT, 1 January 1913.
} 


\section{Conclusion}

Returning to Jeanne Boydston and the question of gender distinctions, the example of the Bible Students suggests the potential that non-binary understandings of gender can present for American religious history. Even in the relatively conservative era of Victorian America, gendered meanings could and did become blurred in the practice of harvest work. The act of consecration demanded that men and women place faith above gender in how they constructed their roles as harvest workers, a spiritual logic that eroded the distinctions between the sexes. This created the potential for some men and women to imagine consecrated identities that obscured and blurred the gender binary, even if the Russells never entirely endorsed such a view. Bible Students could envision themselves as soldiers, sufferers, or penitents in the field, and indeed often drew on all these languages when constructing their spiritual identities within the movement. The Russells never entirely endorsed such a view, but for the first two decades of the Tower the practice of the harvest destabilized the meaning of gender within the Bible Students. After 1900, a liminal process of institutionalization shifted the definition of consecration and forefronted gender roles as the organization centralized. The possibilities for gender fluidity narrowed as a result, reducing the incoherencies, undercurrents, and discontinuities within gendered systems that could exist among the Bible Students. 